WORKING PAPER · NO. 2020-48

\title{
Economic Activity and the Value of Medical Innovation during a Pandemic
}

Casey B. Mulligan

APRIL 2020 


\section{Economic Activity and the Value of Medical Innovation during a Pandemic*}

By Casey B. Mulligan

April 16, 2020

\section{Executive Summary}

We are currently fighting a war against the COVID-19 virus. The war presents an obvious and massive tradeoff between "guns" - activities whose primary purpose is war production - and "butter," which refers to the normal activities of households and businesses. Without any improvement in our techniques for fighting the war, the sacrifices by households and businesses will be staggering and historically unprecedented. This document enumerates and quantifies the sacrifices, showing why negative 60 percent is an optimistic projection for the annualized growth rate of U.S. GDP in 2020 Q2 if the nonessential businesses were not allowed to operate during that quarter. The lost surplus from market activity, while massive, nonetheless understates the true costs of the sacrifices that households and businesses are making, which I estimate to total almost $\$ 15,000$ per household per quarter before counting any health costs or monetizing any intrinsic costs of forgone civil liberties. This is why better techniques for fighting the war are incredibly valuable.

Medical innovation can reduce the intensity and duration of the war, yet Federal policy continues to be a major barrier to that innovation. Valuable treatments may come from drugs in the early stages of development, drugs that have been proven safe but not yet federally approved, as well as the repurposing of drugs that were originally invented for different medical conditions. Also valuable are new equipment and techniques for prevention, such as the manufacture of diseasetesting equipment and tools for tracing contacts of infected patients.

Medical innovation is not limited to the activities of health professionals. Business and civic organizations can also innovate how they accomplish their traditional missions while mitigating harms from COVID-19. To name an example, retailers such as Walmart and Whole Foods have

\footnotetext{
${ }^{*}$ I appreciate discussions with Luke Froeb, Kevin Murphy, Eric Posner, Eric Sun, and Joel Zinberg and financial support from the Program on Foundational Research on Health Care Markets at the Becker-Friedman Institute and from Citadel LLC.
} 
implemented special shopping hours for senior citizens, who are more vulnerable to the virus, so that they do not have to mingle with nonelderly shoppers. But organizations can hardly innovate when they are prohibited from operating.

Three novel methods and data indicate that the shutdown of "nonessential" businesses puts market production 25-28 percent below normal in the short run. Those methods include (i) historical data on the relationship between annual GDP and the number of workdays in a year, (ii) historical data on the fraction of government labor that has been deemed "essential" during government shutdowns, and (iii) new data from Bick and Blandin (2020) on the amount and location of aggregate work hours circa April 1, 2020.

Market production is not synonymous with welfare because factors of production can move into the nonmarket sector, which itself is economically important even in normal times. However, there are two reasons why the dollar amount of the reduction in GDP understates the welfare cost of a shutdown. The first reason is that GDP measures only averages, whereas the direct effects of shutdown are unequally distributed. The inequality apparently has costs by itself, because governments attempt to mitigate those costs by implementing relief efforts that will further reduce GDP both during the shutdown and afterwards. This document estimates a lower bound from the deadweight costs of taxation - about $\$ 2$ trillion per year that the shutdown lasts - that will someday be required to finance the relief efforts. The second reason is that shutting down non-essential businesses makes the nonmarket sector less productive too because the sector is starved of market inputs. Human capital accumulation is an important instance, with more than 70 million children and young adults normally enrolled in school and tens of millions more would be accumulating skills during the early phase of their careers.

I estimate that the shutdown of nonessential businesses reduces market production by almost $\$ 6$ trillion per year of shutdown. Relief efforts further reduce the current value of future economic activity by about $\$ 2$ trillion per year of shutdown. Black markets and additional time in the nonmarket sector replace about $\$ 2$ trillion of the $\$ 8$ trillion of lost market production. I estimate that the value of nonmarket production falls below what it would be if the normal market inputs were available by about $\$ 1$ trillion per year of shutdown. The sum of these puts the welfare costs at about $\$ 7$ trillion per year of shutdown. 


\section{Real Costs of "Shutdown"}

Government officials around the world have ordered businesses shut and families to stay in their homes except for essential activities. My purpose here is to enumerate and quantify the real economic costs of fighting the war in this way. This report estimates the opportunity costs of shutdown relative to a normally functioning economy. This is the relevant comparison for the purposes of policy decisions affecting innovation in medicines and disease testing, as well as policies that facilitate scaling the manufacturing and distribution of protective equipment and therapies that could end the shutdown earlier. ${ }^{1}$

To be clear, the cost-enumeration exercise can be consistent with a conclusion that the war is worth fighting - that depends on quantifying the benefits, which are surely significant given the value that people place on health and longevity. Although this report does not address the question of whether a shutdown is better than no policy response, it offers some of the essential ingredients for such an analysis. No policy response would itself involve economic contraction during the period of time in which no treatment or vaccine is available, although such a contraction is expected to cost far less because individuals and business would still be free to pursue the activities that are most valued to them (Mulligan, Murphy and Topel 2020).

When it comes to projecting the welfare costs of shutting the economy, scholars have the advantage of almost a century's worth of collective experience on measuring economic activity in market economies. We have the system of national accounts, which was developed by economists based on the principles of welfare economics. ${ }^{2}$ Gaps in the national accounts are well known and quantified in many cases.

\footnotetext{
${ }^{1}$ The comparison to a normally functioning economy is relevant even if a full recovery does not occur immediately upon the arrival of an innovation, as long as the arrival is the beginning of a time path to full recovery. The comparison is also relevant to the extent that future innovation permits a second wave of the disease to be mitigated or prevented.

${ }^{2}$ Simon Kuznets, who won one of the early Nobel Prizes in Economic Science, made some of the early and major contributions to national accounting.
} 
The shutdown method of fighting the war on the virus directly affects how people allocate their time. That includes what they do, where they do it, and with whom. Because normal time allocation includes elements of saving and capital accumulation, such as learning skills, the economic effects of the war are felt into the future as stocks of physical and human capital are reduced. For enumeration purposes, I distinguish market production activities from all other activities, especially because market production is counted in conventionally-measured GDP whereas leisure activities are not. Although I refer to the non-market activities as "leisure," they include religious gatherings and forms of effort such as student effort in school and effort put toward housework. Both market production and leisure activities are significantly affected by shutdown.

\section{I.A. Net Costs Associated with Market Production}

Shutdown reduces the amount and effectiveness with which people work. The effects of this can be measured on either the production side of the national accounts, as the value of goods and services not produced, or the income side as reductions in total incomes. Either approach yields the same result, up to measurement error. ${ }^{3}$ However, the incidence - the distribution of impact across industries, occupations, and income groups - is different from the production and income perspectives.

Momentarily putting aside costs associated with leisure activities, the shutdown can be analogized with a change in the number of holidays and weekends ("nonwork days"). A wellstudied, albeit obscure, element of national income accounting is the adjustment for the fact that the number of nonwork days normally varies from year to year. ${ }^{4}$ A normal year has about 251 working days and about 114 nonworking days. ${ }^{5}$ The national accountants have found that adding a nonwork day to the year reduces the year's real GDP by about 0.1 percent and have

\footnotetext{
${ }^{3}$ Adding the opportunity costs of production to the reductions in incomes would be double counting.

${ }^{4}$ Leap years also create variation in the total number of days.

${ }^{5}$ A year has 52 weeks plus an additional one or two days, for a total of between 104 and 106 weekend days. There are ten Federal holidays. The second quarter always has exactly thirteen weeks and one Federal holiday.
} 
been applying this estimate to both the production and real income accounts. ${ }^{6}$ Adding a nonwork day to a quarter would therefore reduce the quarter's unadjusted real GDP by about 0.4 percent.

Extrapolating from this finding, removing all of the working days from a quarter is 62 or 63 times this, or 25 percent. In other words, if seasonally-adjusted GDP 2020-Q2 would have been $\$ 5.5$ trillion at a quarterly rate, then changing all of that quarter's working days to the functional equivalent of a weekend or holiday would reduce the quarter's GDP to $\$ 4.2$ trillion. ${ }^{7}$ Applying the same approach to 2020-Q1, with a shutdown occurring for one-eighth of the quarter, 2020Q1 real GDP (in 2020-Q2 prices) would be \$5.4 trillion. The quarter-over-quarter growth rate of seasonally-adjusted real GDP would, expressed at annual rates, therefore be -10 percent in Q1 and -63 percent in Q2. ${ }^{8}$ The Q2 growth rate would be less negative to the extent that a shutdown was in place for only part of the quarter or for part of the country.

Shutdown is not exactly the functional equivalent of changing workdays to weekends or holidays. On one hand, a segment of the workforce will engage in telework during shutdown that they would not perform on a normal weekend or holiday. Other segments or regions will be exempt from shutdown. This by itself suggests that the $\$ 4.2$ trillion estimate is too pessimistic. On the other hand, much of the normal weekend activity such as restaurants, entertainment, and religious activities is not occurring during shutdown. This by itself suggests that the $\$ 4.2$ trillion estimate is too optimistic. ${ }^{9}$

A second method uses the production side alone and focuses on quantities of capital and labor engaged in production. Labor is reduced by the number of "non-essential" employees, which has

\footnotetext{
${ }^{6}$ European Central Bank (2004). Note that 0.1 percent is much less than $1 / 251$; the estimate implies that the average nonworking day has two-thirds the GDP of a working day.

${ }^{7}$ This is the sum of Table 1's first row with its addendum row.

${ }^{8}$ This assumes a baseline annual growth rate of 2 percent and applies it one for one. The formula for the annualized growth rate in Q2 is $\left(\frac{1-0.004 * 62.5}{1-0.004 * 62.5 / 8}\right)^{4} * 1.02-1=-63$ percent. The normal seasonal adjustment for Q2 reflects, among other things, that $\mathrm{Q} 2$ has one or two more working days than the average quarter. If the national accountants apply this part of the adjustment to 2020 Q2 (despite the fact that it did not have the extra working days), the annualized growth rate would be -65 percent.

${ }^{9}$ During the pandemic the Federal government has created and expanded programs that heavily subsidize furloughs and unemployment. These are policies reducing the Q1-to-Q2 growth rate regardless of whether non-essential businesses are permitted to operate.
} 
been about 30 percent during Federal shutdowns. ${ }^{10}$ In some of the industries, real capital will continue to be used, albeit by fewer employees. Other industries will not use their capital, although it may be repurposed, such as a hotel being used as a hospital ward. To be conservative, I assume that few industries increase their labor-capital ratio. ${ }^{11}$ The reduction in capital input is therefore somewhere between 0 and 30 percent; I assume 15 percent. History has repeatedly shown that labor is more important in the production process than capital, so that by the second method real GDP is reduced 26 percent. $^{12}$

A third method takes a similar approach, but measures the labor reduction from a recent survey conducted by Bick and Blandin (2020). They find that working hours per working age adult declined 28 percent from February. Moreover, among those working in February 2020, between 59 and 61 percent are now absent from their workplaces either due to not working or working from home. ${ }^{13}$ If half of the capital in those workplaces is idle and not replaced by capital located in home offices, then capital utilization has fallen by 30 percent and GDP by 28 percent. My estimate of the GDP effect of shutdown, shown in Table 1 and what follows, is the average of this 28 percent and the aforementioned 25 percent based on holidays.

\footnotetext{
${ }^{10}$ Katz (2019). The non-essential share has not yet been measured for government-mandated private-sector shutdowns, which suggests that the holiday-weekend method should receive more weight. On the other hand, the new data from Bick and Blandin may be closer to the government-shutdown method. Given that I obtain almost the same result for the two methods, their weighting is not critical to the analysis.

${ }^{11}$ Using their labor is different than keeping the labor on the payroll. An unused worker still on the payroll does not contribute to current output.

${ }^{12}$ Barro, Ursúa and Weng (2020) estimate that, if the COVID-19 epidemic were a scaled version of the 1918 Spanish Flu, real GDP would fall less than eight percent. The authors note that the current pandemic is unique in that "countries have been pursuing a policy of lowering real GDP," which are the lockdowns that are the subject of this report. Looking at the current pandemic, Eichenbaum, Rebelo, and Trabandt (2020) estimate that aggregate consumption and GDP (their model has no investment) will fall up to 20 percent.

${ }^{13}$ I obtain this range by assuming that (i) the share of February 2020 employment from home was ten percent, corresponding to Bick and Blandin's estimate from the 2017 and 2018 March ATUS, (ii) that those previously working at home are disproportionately likely to keep their jobs, and (iii) no jobs that were being done at home are now done outside the home.
} 
Table 1. Welfare Effects of Shutting Down "Non-essential" Activities

April 2020

\begin{tabular}{|c|c|c|c|c|}
\hline \multirow[b]{2}{*}{ Value of: } & \multirow{2}{*}{$\begin{array}{r}\text { Millions of } \\
\text { persons involved }\end{array}$} & \multicolumn{3}{|c|}{ Welfare effect, $\$$ billions } \\
\hline & & Per workday & Per quarter & Per year \\
\hline Market production & -48 & -23.6 & $-1,480$ & $-5,918$ \\
\hline Deadweight cost of relief policy & 159 & -7.8 & -488 & $-1,951$ \\
\hline Nonmarket labor inputs & 48 & 7.1 & 444 & 1,775 \\
\hline \multicolumn{5}{|l|}{ Nonmarket productivity } \\
\hline Black markets & NA & 2.1 & 135 & 539 \\
\hline School time & 73 & -1.1 & -72 & -287 \\
\hline OJT taken out of earnings & 111 & -0.4 & -27 & -107 \\
\hline Time of adults normally OLF & 95 & -2.5 & -156 & -626 \\
\hline Time of displaced workers & 48 & -1.2 & -78 & -313 \\
\hline Leisure time of workers & 111 & -0.7 & -46 & -183 \\
\hline Total, $\$$ billions & & -28.2 & $-1,768$ & $-7,071$ \\
\hline Total, \$ per household & & -231.9 & $-14,555$ & $-58,219$ \\
\hline
\end{tabular}

Addendum: Market production (GDP) absent shutdown

\$ billions

88.3

5,541

22,165

\section{Notes}

The table shows point estimates of costs that could be netted against point estimates of health benefits such as deaths averted by shutdown.

The impact on market production is taken as $-26.7 \%$, which is the average of input and output methods. Welfare costs of market production also reflect the opportunity costs of capital out of service.

Deadweight costs of relief policy are financing costs, without any distribution costs.

School time is for full-time students only.

The estimates do not include the entire effect of expanding social insurance, which would be to further shift inputs from the market to nonmarket sectors. The additional demand for social insurance itself reflects costs of shutdown that are not captured by the averages.

The GDP estimates do not reflect black markets. But, as seen with border patrol and the war on drugs, any government regulation attempting to block valuable gains from trade will result in black market activity. Businesses will also work the gray area, lobbying and distorting their operations to have more activities declared "essential."

Black-market activity is far less productive than legitimate activity, which is why it does not come close to replacing the "non-essential" sales that were banned. But it still has value, which 
is why the best welfare effects of shutdown may be less pessimistic than analysis assuming zero black market. ${ }^{14}$ I assume that black markets replace 25 percent of the gains from trade, based on studies of illegal drugs. ${ }^{15}$ However, value generated in black markets is typically not measured as part of GDP. Indeed, black markets compete with legitimate markets for the factors of production and by this channel would reduce measured real GDP even more than would occur without black markets (Fleming, Roman and Farrell 2000). Because the black market is entirely different in terms of measurement (albeit perhaps similar in terms of transactions), Table 1's "nonmarket" heading shows the $\$ 539$ billion annual value of black market transactions that were formerly in the legitimate economy. Subsection I.C. below discusses other activities, such as leisure time and the effort of students, that are more intrinsically nonmarket.

Although the national income accounts were designed on the basis of the principles of welfare economics, GDP growth is not exactly a benefit and GDP reduction is not exactly a welfare cost because valuable activities and assets such as home production, elements of human capital accumulation, and environmental quality are not yet recognized in the official national accounts (Hartwick 1990, Nordhaus and Kokkelenberg 1999, Jorgenson 2010). However, as discussed further below, the GDP losses cited above prove to reasonably approximate more comprehensive welfare losses.

\section{I.B. The Incidence of the Net Costs}

The massive costs of shutting down "non-essential" activities are not shared equally among Americans. Some workers are still able to draw a normal salary even while their industry is less active. Others work in industries such as parts of healthcare that are booming as a result of the pandemic. Because the aggregate reduction in the value of what is produced must equal the aggregate reduction in total income, the costs of shutdown will fall disproportionately on the remainder of the population that are not in these circumstances.

\footnotetext{
${ }^{14}$ But government regulators can hardly defend their shutdown regulations on the grounds that they will not be obeyed! Moreover, black markets add another social cost by eroding respect for law and order.

${ }^{15}$ The war on drugs increases the retail price (and unit cost to suppliers) by a roughly a factor of four and reduces the quantity consumed by a factor of two (Jaffe, et al. 2019, Figure 12-1). Illegal drug sellers have had many years to accumulate organizational and other capital that lockdown violators did not. On the other side, drug war enforcers have had many years that lockdown enforcers have not.
} 
Table 1 shows only averages. Public programs are being created and expanded with the intention of helping some of those who are disproportionately bearing the costs. Redistribution policy may help distribute the aggregate costs more fairly, but in no way can it reduce the aggregate cost. Even while these policies assist those who are not working because of the pandemic, they do not replace the work and production that the workers would have been doing. The fact that the demand for redistribution increases in these situations suggests that the inequality itself is a cost large enough that people are willing to tolerate further increases in the average costs (i.e., further decreases in GDP, both during the shutdown and afterwards) in order to mitigate the costs for those disproportionately affected (Mulligan 2014, Mulligan 2012, Chapter 10). In other words, the costs of inequality are reduced by replacing them with a different kind of cost: reductions in GDP during and after the shutdown. To the extent that the costs of inequality are not fully eliminated, the costs associated with the relief-induced GDP reductions (estimated in this document) are a lower bound on the cost associated with the inequality.

The CARES Act and the FFCRA Act are the two largest relief packages passed in the U.S. The Congressional Budget Office (2020a, 2020b) estimates that combined their financing will require $\$ 1.95$ trillion in present value of additional taxes or reduced Federal spending. The collection of those taxes, or reduction in that spending, involves costs that I approximate as half of the amount of the tax. ${ }^{16}$ I further assume that the relief package is adequate for a shutdown of only one half year; a shutdown lasting a full year would therefore have deadweight financing costs of $\$ 1.95$ trillion. In addition to the financing costs, the distribution of the funds from the relief packages will also reduce GDP by reducing incentives to work, reducing the incentives of workers to shift into industries that need them most, and otherwise distorting the behavior of individuals and businesses (Mulligan 2012). I have not yet estimated the fund-distribution costs or include them in Table $1 .{ }^{17}$

\footnotetext{
${ }^{16}$ My approximation is based on the "marginal cost of public funds" (Dahlby 2008), as estimated for the U.S. economy by CEA (March 2019) by considering the various implicit and explicit taxes on income, payroll, and sales. For this purpose I assume, as Atkinson and Stern (1974) do, that the marginal cost of public funds is the same regardless of when the financing occurs and whether it occurs from less spending or more taxes. Note that the costs of relief packages would be much larger if their revenue requirements push the U.S. to the top of its Laffer curve. ${ }^{17}$ Mulligan and Blase (2020) calculate enough to show that distribution of CARES funds will noticeably reduce aggregate employment.
} 


\section{I.C. Net Costs Associated with Nonmarket Activities}

The nonmarket/home sector is affected by shutdown through two basic channels, as shown in Table 1. The first channel is discussed above: the nonmarket sector has additional labor that has been forced out of the market sector. The second channel is that the nonmarket sector becomes less productive, both for the nonmarket time that normally exists as well as the additional nonmarket time coming from the market sector, because even in their nonwork activities people are restricted in terms of where they go and how they associate with others. The percentage change in the value created in the nonmarket sector combines the two channels and is approximately the sum of the (positive) percentage change in labor input and the (negative) percentage change of nonmarket productivity. ${ }^{18}$

An important example of the second channel is the time allocation of children and young adults who would normally be enrolled in school and now spend their time at home. Their learning from normal face-to-face interactions with teachers and fellow students is not fully reflected in GDP, but is nonetheless valuable. In other cases, as with religious gatherings, entertainment, and tourism, shutdowns reduce the value of these activities by limiting how people can congregate and the market inputs that can be used as part of the leisure activity.

Because the national accounts are based on the principles of welfare economics, GDP would ideally capture value created or destroyed in both the market and nonmarket sectors. Measurement challenges have so far limited the scope of conventional GDP measures to the market sector. Conventional GDP measures therefore miss the value of additional nonmarket time added by the shutdown (the first channel) as well as the reduced productivity of nonmarket time (the second channel). This section provides estimates of the two, which can be added to the GDP losses from Section I.A to arrive at a welfare loss of shutdown as compared to normal economic activity.

To estimate the nonmarket value of added labor, I use the short run of the neoclassical growth model, which is essentially a labor supply and demand framework. The average nonmarket

\footnotetext{
${ }^{18}$ The approximation is exact when the changes are measured in logarithms rather than percentages.
} 
value of time is below the after-tax real wage that would normally prevail, but above the marginal value of time with a shutdown, which I estimate to be 49 percent of the former. ${ }^{19}$ With a 48 percent marginal tax rate (inclusive of implicit taxes on labor income), the total nonmarket value of the extra time is about $\$ 7$ billion per day (see Table 1), or about 30 percent of the reduction in real GDP. Simply put, about two-thirds of the \$24 billion daily GDP loss is a welfare loss, even without considering any productivity change in the nonmarket sector or anything about the incidence of the GDP loss.

Full-time schooling, where there are normally about 73 million children and young adults enrolled, is the part of the non-market sector's productivity loss that is easiest to quantify. Their time and efforts, which are known as "foregone earnings" and not counted in conventional GDP measures, are combined with direct schooling costs such as the education industry's payroll and capital expenses because the students, their parents, or their community value the results of schooling. I quantify the nonmarket component of the value of school according to two methods: one based on inputs and the other based on outputs.

For the input approach, note that the direct costs of schooling (e.g., salaries for teachers and administrators) were $\$ 370$ billion in 2018. Various studies, such as Breton (2013), estimate that foregone earnings are about 102 percent of the direct costs, which would be $\$ 377$ billion in 2018 , or about $\$ 4.3$ per hour that the average student was in school.

An important output of schooling is enhanced earnings during adulthood. If a yearlong shutdown resulted in today's students reaching adulthood with an average of one year less of schooling, that would reduce their earnings by what labor economists call "the rate of return to schooling” (Becker 1964/1993, Mincer 1974). Taking that return to be 8 percent per year of schooling and the present value of lifetime earnings to $\$ 417,000$ (that corresponds to a starting salary of about $\$ 25,000$ ), losing a year of schooling costs $\$ 33,000$ from the perspective of a young adult transitioning from school to the labor market. For a student 8 years before that point, the present value of that loss is about $\$ 21,000$ or about $\$ 17.50$ per hour spent in school. As noted above, about half of that output should be attributed to teachers and administrators,

${ }^{19}$ This assumes a wage elasticity of labor supply of $1 / 2\left(0.49=0.7^{2}\right)$. 
thereby putting the value of output generated by the average student's hour in school at $\$ 8.84$. The average estimate from the two approaches is therefore $\$ 6.58$ per hour of student time.

Some schooling still occurs during shutdown, such as learning remotely. I take the loss of student output attributable to their time and effort to be half of the $\$ 6.58$, or about $\$ 3.29$ per hour that they would have been in school. As shown in Table 1, the lost value of schooling is $\$ 287$ billion per year of shutdown, or $\$ 73$ billion per quarter. ${ }^{20}$

Learning does not stop at graduation. Post-graduation workers learn on the job, which shifts the composition of their compensation toward skill acquisition and away from the cash and other fringe benefits that are part of conventionally measured GDP (Rosen 1972). Although the market sector may be the physical location of this learning, I count the foregone earnings as "nonmarket" because it is usually unmeasured. I estimate the value of foregone earnings using the cross-section age-earnings profile and the average of two estimates of the age-training profile (Mulligan 1998). During a shutdown, this learning does not occur for 30 percent of the workforce, although (as with market production) I assume that about one-third of its value is replaced with nonmarket activity. The net opportunity cost associated with on-the-job training (OJT) is therefore about $\$ 107$ billion at an annual rate, as shown in Table 1.

The normal population has even more adults not in the labor force than full-time students, not to mention all of the time that workers normally spend outside of work. If a shutdown also reduced the hourly value of their time by $\$ 3.29$ for 2000 hours per year for those out of the labor force and for 500 hours per year for those who work, that would be a loss of $\$ 1.5$ trillion at an annual rate.

\footnotetext{
${ }^{20}$ Note that I estimate private values of schooling. The fact that schooling is compulsory at younger ages and subsidized at all ages suggests that the social value of schooling might be even greater. If so, the lost social value is even greater than shown in Table 1.
} 


\section{The current costs of barriers to medical innovation and economic recovery}

Medical innovation can reduce the duration and severity of pandemics. In doing so, innovation reduces the duration and severity of the direct health costs as well as the costs of economic shutdowns intended to mitigate the health costs. As long as it remains a major barrier to medical innovation, regulation will unnecessarily add to the economic and health costs of the current pandemic.

Innovation is not finished when scientists discover a new medicine, device, or technique and demonstrate its safety. Medicines and equipment will need to be manufactured and distributed on a massive scale. Personnel will need to be trained to administer new treatments. These processes can be slowed by regulatory barriers ranging from Federal inspections of facilities manufacturing drugs and devices to state occupational licensure and regulation of telecommunications companies.

Although not new, disease testing and contact tracing are essential techniques that are scalable in principle, but currently unavailable in the United States in more than small quantities. Regulatory barriers slow both the manufacturing of these devices and techniques as well as the development of more scalable methods for distributing them.

\section{II.A. The Value of Medical Innovation}

Medical innovation has proven to be enormously valuable. Between 1970 and 1998, the average year of medical discoveries added more than a trillion dollars to national wealth (Murphy and Topel 2003). These include discoveries that reduced mortality from premature birth, heart disease, and cancer. All age groups benefitted from new drugs that reduce mortality, in amounts that far exceed the research and development costs for those drugs (Lichtenberg 2003). Vaccines and treatments for viruses are especially active areas of medical research because each year's viruses have unique genetics (Council of Economic Advisers September 2019). 
CEA estimated that the value, in terms of reduced mortality, of a vaccine against a flu pandemic would be up to $\$ 4$ trillion if it could be produced and distributed to millions of patients. A vaccine or treatment for COVID-19 would not only reduce mortality but would also save \$28 billion for each working day that normal economic activities could be resumed. ${ }^{21}$ Unlike the mortality savings, the value of resuming these activities is higher the further that the pandemic has progressed.

Twenty-two COVID-19 medicines were in development as of March 2020 (PhRMA 2020). In addition, physicians, hospitals, and pharmaceutical companies are experimenting with existing drugs that were approved for other conditions but have some promise to help coronavirus patients. Employers and workers are devising ways to work that are less conducive to spreading the virus. At the intersection of the medical and business communities are virus testing and treatment that would assist in the efforts to have safer workplaces.

\section{II.B. A Pandemic Skews the Calculus of Regulation: The Case of Drug Development}

Regulatory barriers reduce both the number of patients who will directly benefit from a vaccine or treatment and the number of treatments that are available. Those barriers, which cost an average of $\$ 1.5$ billion per approved drug, include processing time by a regulatory agency, added costs for clinical trials, and agency fees (DiMasi, Grabowski and Hansen 2016).

The average U.S.-approved new pharmaceutical and biotech product spends eight years in the approval process at the Food and Drug Administration (FDA), which delays patient benefits and supplier revenues by that length of time (Jørring, et al. 2017). For each approved product, there are more than four products that fail the FDA approval process.

FDA new-drug approval consists of several phases. Phase I is a clinical trial to determine the safety of the drug and lasts an average of 16 months. Phase I expenses, including those for drugs

\footnotetext{
${ }^{21}$ The savings from ending the shutdown cannot be added to CEA's mortality savings because the shutdown itself presumably helped reduce mortality from the pandemic.
} 
that are not approved, are about a fourth of total drug development expenses. Eight of the twenty-two COVID-19 medicines in development have already reached Phase I or beyond.

U.S. clinical trial costs are about double of what they are in middle-income countries. Clinical trials must either be conducted in the U.S. or for foreign trials be demonstrated to adhere to FDA standards.

Only drugs shown to be safe in Phase I proceed to the next phases, which are clinical trials to demonstrate effectiveness. The later phases add expenses and postpone the date when the drug can be distributed to patients, but the FDA believes that the efficacy trials provide valuable public information that many companies would not provide if they were not required for approval (Food and Drug Administration 2017). Even after a drug is approved, each manufacturer of it must be FDA approved, which in many cases involves the bureaucratic delays associated with a foreign manufacturing site visit.

FDA new-drug approval is given only for specific indications (disease or medical condition) and dosage. An approved drug can be prescribed for unapproved ("off-label”) indications and dosages. Although the FDA does not have jurisdiction over physician practice, the FDA may create malpractice and third-party payment concerns around off-label prescribing by saying that the prescribing physician must be well informed about the relevant medical evidence, which does not yet exist for the COVID-19 indication. ${ }^{22}$ Off-label prescriptions may be an especially fertile area for COVID-19 innovation because the drugs have already been shown to be safe and have proven manufacturing and distribution facilities. The drugs are often available as generics.

Outside the U.S., a large number of COVID-19 patients have received a range of off-label therapies such as hydroxychloroquine and remdesivir. ${ }^{23}$ Even if the lack of a safe harbor for offlabel prescriptions delayed the U.S. adoption of off-label COVID-19 prescriptions by a few days, the delay costs would be in the billions of dollars.

\footnotetext{
${ }^{22}$ Food and Drug Administration (1998). Malpractice concerns may also incentivize hospitals to stockpile such drugs in anticipation of the release of medical evidence is that justifies off-label prescribing.

${ }^{23}$ Kalil (2020). Off-label Chloroquine and Hydroxychloroquine are being used in the U.S. to some extent.
} 
Pandemics have fundamentally different regulatory costs and benefits. A pandemic involves a contagious disease, which means that a vaccine or treatment that is somewhat unsafe to the patient may nonetheless confer benefits on the general population by making the patient less contagious. More important, pandemics are also different in that most of the demand for a vaccine or treatment occurs in a span of just a few months. As acknowledged by the passage of the Right to Try Act, patients with short horizons do not benefit from waiting until regulators can ensure the efficacy of a new treatment. ${ }^{24}$ Today the entire world has a short horizon when it comes to COVID-19 medicines. What good is a safe COVID-19 medicine that emerges only next year when it is finally proven to be effective in trials? To put it another way, the limited duration of a pandemic is a reason why the entire population should be allowed to enter the laterphase "trials."

\section{II.C. Barriers to Disease Testing and Contact Tracing}

Although less exotic, some of the most valuable innovation can be the discovery and implementation of ways to reduce infections in the workplace and the general population. There is also a need to expand testing capacity, to consider testing in the workplace (which requires FDA approval), and to implement contact tracing on a large scale (which has other regulatory barriers). The economic shutdown itself can be a significant barrier to these kinds of progress because it closes the workplaces where many of the new practices would be administered.

The presence of a disease-causing virus can be detected by gathering biological samples from a patient and sending them to a laboratory for testing. This requires clinical personnel to gather and record samples as well as testing equipment in the laboratories. Following a positive test result, contact tracing reduces disease transmission (as well as delivering treatments earlier in the disease progression) by identifying contacts and providing those contacts with follow-up monitoring and information (World Health Organization 2017).

\footnotetext{
${ }^{24}$ In offering various "Fast Track" and "compassionate use" options for the later phases, especially for drugs filling an "unmet medical need," the FDA essentially acknowledges that lengthy approval processes are not necessary in every situation.
} 
The FDA has removed some of the barriers to developing and implementing COVID-19 tests, although it has activated additional barriers such as those associated with a legally-declared public health emergency (Boburg, et al. 2020).

Countries such as Iceland and South Korea, conducted COVID-19 testing and contact tracing early and therefore had the luxury of operating on a smaller scale. By now the United States needs more scalable technologies and protocols. Digital contact tracing has great promise. One digital proposal is "A mobile phone App can make contact tracing and notification instantaneous upon case confirmation. By keeping a temporary record of proximity events between individuals, it can immediately alert recent close contacts of diagnosed cases and prompt them to self-isolate" (Ferretti, et al. 2020). Other proposals include a centralized database of mobile location data to allow authorities to better predict location-specific trends. However, the myriad of longstanding telecommunication regulations can be a barrier to digital tools. Among those are privacy rules that can require mobile and fixed internet service providers to discard any personal data until they individually contact and obtain consent from customers. The state of Maine imposed this requirement in 2019 and other states are considering it. ${ }^{25}$

As shown in Table 1, if any one of the innovations in medicine, testing, manufacturing, or workplace mitigation could accelerate the end of a nationwide shutdown by a single workday, that would be worth almost $\$ 30$ billion (plus the value of health and longevity). If a combination of these innovations could accelerate the end of a nationwide shutdown by just a month, they would be worth $\$ 590$ billion. Accelerating the end by a quarter is worth almost $\$ 2$ trillion.

\footnotetext{
${ }^{25}$ National Conference of State Legislatures (2019). The Federal government imposed the requirement in 2016, but the rule was overturned in 2017 by President Trump and the $115^{\text {th }}$ Congress, saving consumers more than $\$ 10$ billion annually (Council of Economic Advisers February 2020).
} 


\section{Conclusions}

Shutting down the economy, which is being done as protection against the harms of COVID-19, has tremendous costs relative to a normally functioning economy. The reward to finding alternative protections that allow more normal economic activity is therefore commensurately tremendous. Medical innovation may provide such alternatives, but is currently handicapped by Federal and state regulations, including the shutdowns themselves.

Although this report does not address the question of whether a shutdown is better than no policy response, it offers some of the essential ingredients for such an analysis. ${ }^{26}$ No policy response would itself involve economic contraction, especially because work is so heavily taxed. Shutdown policy therefore costs less relative to no policy response than it does relative to a normally functioning economy. On the other hand, the costs of economic contraction are convex, which suggests that the amount of contraction without a policy response would be less than shutdown, especially in the metric of welfare costs.

${ }^{26}$ Note that Table 1 contains point estimates of costs and therefore is not comparable to "worst case" estimates of health benefits. 


\section{Bibliography}

Atkinson, Anthony B., and Nicholas H. Stern. "Pigou, taxation and public goods." The Review of economic studies 41 (1974): 119-128.

Barro, Robert J., José F. Ursúa, and Joanna Weng. "The Coronavirus and the Great Influenza Pandemic: Lessons from the "Spanish Flu" for the Coronavirus's Potential Effects on Mortality and Economic Activity." NBER working paper, no. 26866 (March 2020).

Becker, Gary S. Human capital: A theoretical and empirical analysis, with special reference to education. University of Chicago Press, 1964/1993.

Bick, Alexander, and Adam Blandin. "Real Time Labor Market Estimates During the 2020 Coronavirus Outbreak." alexbick.weebly.com. April 15, 2020. https://alexbick.weebly.com/uploads/1/0/1/3/101306056/bb_covid.pdf.

Boburg, Shawn, Robert O'Harrow Jr., Neena Satija, and Amy Goldstein. "Inside the coronavirus testing failure: Alarm and dismay among the scientists who sought to help." The Washington Post, April 3, 2020.

Breton, Theodore R. "Were Mankiw, Romer, and Weil right? A reconciliation of the micro and macro effects of schooling on income." Macroeconomic Dynamics 17 (2013): 10231054.

Christian, Michael S., and others. Human capital accounting in the United States: 1994 to 2006. BEA, 2010.

Congressional Budget Office. "Preliminary Estimate of the Effects of H.R. 6201, the Families First Coronavirus Response Act." Congressional Budget Office. April 2, 2020a. https://www.cbo.gov/publication/56316.

—. "Preliminary Estimate of the Effects of H.R. 748, the CARES Act, Public Law 116-136." Congressional Budget Office. April 16, 2020b. https://www.cbo.gov/publication/56334.

Council of Economic Advisers. Economic Report of the President. Executive Office of the President, February 2020.

Council of Economic Advisers. Economic Report of the President. Executive Office of the President, March 2019.

Council of Economic Advisers. Mitigating the Impact of Pandemic Influenza through Vaccine Innovation. Executive Office of the President, September 2019.

Dahlby, Bev. The marginal cost of public funds: Theory and applications. Cambridge, MA: MIT press, 2008.

DiMasi, Joseph A., Henry G. Grabowski, and Ronald W. Hansen. "Innovation in the pharmaceutical industry: new estimates of R\&D costs." Journal of health economics 47 (2016): 20-33.

Eichenbaum, Martin S., Sergio Rebelo, and Mathias Trabandt. "The Macroeconomics of Epidemics." googlegroups.com. March 23, 2020. https://fb8280a8-a-62cb3a1a-ssites.googlegroups.com/site/mathiastrabandt/home/downloads/EichenbaumRebeloTraban dt_EpidemicsMacro.pdf?attachauth=ANoY7coRODwA_z1gJoSLHsTEXF0IQcWOQbF P5bfX9cHSypuO2NuwJPyq7T2A4p2wdppO10jWVgmAzN4-16irT7vZqkwvBs8_8PNb3hs0ZJmZtr.

European Central Bank. "The impact of the number of working days on euro area GDP in 2004." Monthly Bulletin, June 2004: 51-63.

Ferretti, Luca, et al. "Quantifying SARS-CoV-2 transmission suggests epidemic control with digital contact tracing." Science (American Association for the Advancement of Science), 2020.

Fleming, Matthew H., John Roman, and Graham Farrell. "The shadow economy." Journal of International Affairs, 2000: 387-409. 
Food and Drug Administration. "'Off-Label" and Investigational Use Of Marketed Drugs, Biologics, and Medical Devices." fda.gov. January 1998. https://www.fda.gov/regulatoryinformation/search-fda-guidance-documents/label-and-investigational-use-marketeddrugs-biologics-and-medical-devices.

—. "22 Case studies where phase 2 and phase 3 trials had divergent results." fda.gov. 2017. https://www.fda.gov/media/102332/download.

Hartwick, John M. "Natural resources, national accounting and economic depreciation." Journal of Public Economics 43 (1990): 291-304.

Jaffe, Sonia, Robert Minton, Casey B. Mulligan, and Kevin M. Murphy. Chicago Price Theory. Princeton University Press (ChicagoPriceTheory.com), 2019.

Jorgenson, Dale W. "A new architecture for the US national accounts." Review of Income and Wealth 55 (2009): 1-42.

Jorgenson, Dale W. "Human capital and the national accounts." Survey of Current Business 90 (2010): 54-56.

Jørring, Adam, Andrew W. Lo, Tomas J. Philipson, Manita Singh, and Richard T. Thakor. "Sharing R\&D risk in healthcare via FDA hedges." NBER working paper, no. 23344 (April 2017).

Kalil, Andre C. "Treating COVID-19—Off-Label Drug Use, Compassionate Use, and Randomized Clinical Trials During Pandemics." JAMA, 32020.

Katz, Eric. "Agencies Paid Federal Employees \$3.7 Billion Not to Work During Recent Shutdowns." govexec.com. September 17, 2019. https://www.govexec.com/paybenefits/2019/09/agencies-paid-federal-employees-37-billion-not-work-during-recentshutdowns/159936/.

Lichtenberg, Frank R. "Pharmaceutical Innovation, Mortality Reduction, and Economic Growth." In Measuring the Gains From Medical Research: An Economic Approach, by Kevin M. Murphy and Robert H. Topel, 74-109. Chicago: University of Chicago Press, 2003.

Mincer, Jacob. "Schooling, Experience, and Earnings. Human Behavior \& Social Institutions No. 2." (ERIC) 1974.

Mulligan, Casey B. "Substitution over time: another look at life-cycle labor supply." NBER macroeconomics annual 13 (1998): 75-134.

-. The Redistribution Recession. New York: Oxford University Press (redistributionrecession.com), 2012.

Mulligan, Casey B. "Uncertainty, Redistribution, and the Labor Market since 2007." IZA Journal of Labor Policy 3, no. 8 (2014): 1-16.

Mulligan, Casey B., and Brian Blase. "Congress Can Still Save the Recovery." Wall Street Journal, April 8, 2020.

Mulligan, Casey B., Kevin M. Murphy, and Robert H. Topel. "Some Basic Economics of COVID-19 Policy." Manuscript, Univ. of Chicago, 2020.

Murphy, Kevin M., and Robert H. Topel. "The Economic Value of Medical Research." In Measuring the Gains From Medical Research: An Economic Approach, by Kevin M. Murphy and Robert H. Topel, 74-109. Chicago: University of Chicago Press, 2003.

National Conference of State Legislatures. "2019 Privacy Legislation Related to Internet Service Providers." ncsl.org. December 31, 2019. https://www.ncsl.org/research/telecommunications-and-information-technology/2019privacy-legislation-related-to-internet-service-providers.aspx.

Nordhaus, William D., and Edward C. Kokkelenberg. Nature's Numbers. National Academy Press Washington, DC, 1999. 
PhRMA. "The Biopharmaceutical Industry is Leading the Way in Developing New Vaccines and Treatments for COVID-19." phrma.org. March 13, 2020. https://phrma.org//media/Project/PhRMA/PhRMA-Org/PhRMA-Org/PDF/GI/IndustryResponseCOVID19.pdf.

Rosen, Sherwin. "Learning and experience in the labor market." Journal of Human Resources, 1972: 326-342.

World Health Organization. "Contact Tracing." who.int. May 2017. https://www.who.int/features/qa/contact-tracing/en/. 